\title{
Records of Diatoms and Physicochemical Parameters of Seasonal Ponds in Zaria- Northern Nigeria
}

\author{
A. M. Chia* ${ }^{*}$, S. P. Bako', S.Alonge' and A. K. Adamu' \\ 'Department of Biological Sciences, Ahmadu Bello University, Zaria, Nigeria \\ - Present address: Departamento de Botanica, Universidade Federal de São Carlos, São \\ Carlos, São Paulo, Brasil \\ *Correspondence author: E-mail; chia28us@yahoo.com
}

\begin{abstract}
A study of diatoms species composition, associated with four ponds in Zaria, Northern Nigeria was carried out between November 2005-January 2006 and June-August 2006. Twenty three taxa of diatoms were recorded in the study. Multivariate analysis showed that there were significant positive and negative relationships $(P<0.05)$ between some physicochemical parameters and diatom species in these ponds. CCA results showed that Synedra and Actinocyclus were closely associated with TDS, DO and water hardness; Nitzschia, Frustulia, Navicula and Coscinodiscus with $\mathrm{NO}_{3}-\mathrm{N}$ and alkalinity; and Cyclotella, Tabellaria and Achnanthes with phosphate phosphorus levels.
\end{abstract}

\section{Introduction}

Diatoms grow in a wide range of habitats, which could be oligotrophic or eutrophic, acidic or alkaline, fresh, brackish or marine, standing and flowing waters. Diatoms constitute the highest percentage $(70-95 \%)$ of the flora in aquatic systems, though this percentage usually occurs mainly in the benthic community (Venkateswarlu \& Manikya, 2000; Acs et al., 2004). To date a lot of published works indicate diatoms (and algae) as indicators of water quality (Shubert, 1984; Venkateswarlu, 1981; Vos \& Wolf, 1993; Stachura-Suchoples, 2001; Whitton et al., 1991; Bogaczewicz-Adamczak et al., 2001; Nakanishi et al., 2004). The extent to which diatoms can tolerate the levels of physicochemical parameters makes them potential indicator organisms. This is further supported when significant correlations are observed between diatoms species and water quality of the area or ecological system concerned. Significant correlation is consequent of diatom communities reacting to disturbances in the form of changes in water chemistry.

Diatoms show integrating response to ambient changes in water quality/ environment which may sometimes not be observed by chemical analysis. It is well established that diatoms follow more closely the chemistry of river waters and other aquatic ecosystems (Poulíková et al., 2004; Stenger-Kovács et al., 2007; Tapia, 2008). As a result, they are recommended to be more useful and valuable as tools for monitoring aquatic ecosystems compared to microinvertebrates. They are known to be the most suitable biological components of an aquatic ecosystem to describe the natural and human produced disturbances (Venkateswarlu \& Manikya, 2000). A variety of indices has been derived using diatoms, such as bioindicator value of a species/genus and ecological water quality index.

There is almost no published work on diatoms from ponds in Zaria and other 
northern Nigerian states, although a number of publications are available from other parts of Nigeria which are not necessarily from ponds. A few examples of such studies include Akinyemi et al. (2007 from Awon Reservoir (Oyo), Nwankwo \& Jaiyeola (2001), Onyema \& Nwankwo (2009) from Lagos Lagoon Beach (Lagos), Kadiri \& Opute (2003) from Ikpoba Reservoir, Adesalu \& Nwankwo (2009) from Lekki lagoon (Lagos). Other examples of published works on diatoms from ponds in Nigeria include Ezra (2003) from a brackish water pond in Lagos (South-west Nigeria); and Oladipo \& Williams (2003) from some fish ponds in Lagos, Nigeria (South-west Nigeria). When all the examples cited above are considered, almost $98 \%$ of all the studies are from the southern and eastern parts of Nigeria.

The present study attempts to contribute to scarce amount of published works from northern Nigeria on diatom species composition from seasonal ponds. The present study was aimed at determining the presence of diatoms and physicochemical characteristics of four seasonal ponds in Zaria, Northern Nigeria, to serve as potential water quality bioindicators.

\section{Materials and methods}

\section{Study area}

The four ponds for the study are located in Zaria $\left(11^{\circ} 04^{\prime} 50.55^{2} \mathrm{~N}\right.$, and 7'42' $\left.58.39^{2} \mathrm{~L}\right)$. Three of the ponds are located at Dan Magaji, along Zaria-Kano express way and lying within $2.5 \mathrm{~km}$ of each other. The ponds are called Danmika, Mairabo and Kabama. The last pond, Aviation quarry pond is located opposite the Nigerian College of Aviation Technology, Zaria, Nigeria (Table 1). All the ponds are man made. Danmika, Mairabo and Kabama ponds were formed from the excavations of top soils to use in road construction. They are seasonal in nature, usually containing water for about 8-9 months per year.

Appreciable levels of water are observed from the start of the rains in May, which last till January of the following year. The third pond, Aviation quarry pond is also an artificial pond, which resulted from mining activities, and, sometimes, contains water all year round. The location of the pond is ravaged by stone mining for construction purposes. All the four ponds serve as important sources of drinking water to animals, and irrigation to farmers. In addition, water from the ponds is used for washing and bathing by people that live and

TABLE 1

Physical characteristics of the studied ponds in Zaria, Nigeria

\begin{tabular}{lccc}
\hline Pond & $\begin{array}{c}\text { Characteristic } \\
\text { Area (he) }\end{array}$ & Grid reference & Elevation $(m)$ \\
Danmika & 1.59 & $11^{\prime} 05^{\prime} 39.35^{2} \mathrm{~N}, 7^{\circ} 41^{\prime} 28.99^{2} \mathrm{~L}$ & 648 \\
Mairabo & 3.69 & $11^{\prime} 05^{\prime} 40.73^{2} \mathrm{~N}, 7^{\circ} 41^{\prime} 32.33^{2} \mathrm{~L}$ & 647 \\
Kabama & 3.65 & $11^{\prime} 05^{\prime} 57.56^{2} \mathrm{~N}, 7^{\circ} 41^{\prime} 23.55^{2} \mathrm{~L}$ & 642 \\
Aviation quarry & 0.52 & $11^{\prime} 08^{\prime} 24.38^{2} \mathrm{~N}, 7^{\circ} 40^{\prime} 55.86^{2} \mathrm{~L}$ & 670 \\
\hline
\end{tabular}


work around them. The catchment of the first three ponds is constituted mainly of farmlands while the fourth (Aviation quarry pond) is surrounded by domestic and small scale industrial structures or buildings.

\section{Sampling and analysis of diatoms}

Sampling was undertaken on a monthly interval and this involved four sampling stations per pond from November 2005 to January 2006, and June to August 2006. Water samples were collected at about $30 \mathrm{~cm}$ depth and $1 \mathrm{~m}$ away from the shore (APHA, 1998). Glass jars $(100 \mathrm{ml})$ were used to collect samples for algal analysis, and dark brown glass bottles $(250 \mathrm{ml})$ for $p \mathrm{H}$, dissolved oxygen and conductivity determinations. Samples for other chemical analysis were collected and stored in polyethylene jars $(400 \mathrm{ml})$. Standard biochemical oxygen demand (BOD) bottles were used to collect water for BOD determination. Water samples were collected by dipping the plastic bottles to the sampling depth, then opening them up and allowing them to be filled with water. They were then covered before removing from the depth of sampling. All samples for chemical analysis were either analysed immediately or stored at $-20 \mathrm{C}$ until time for analysis. Samples for diatoms analysis were collected using a cone shaped, silk bolting cloth net with a mouth radius of $20 \mathrm{~cm}$ and concentrate bottle (50 $\mathrm{ml})$.

The concentrate was collected in $100-\mathrm{ml}$ glass jars and fixed immediately with an appropriate volume of Lugol solution to precipitate and preserve diatoms (APHA, 1998). Laboratory treatment and analysis of diatom samples followed the procedures of Prescott (1977), and APHA (1998). Diatom biomass (number of cells per $\mathrm{ml}$ ) was determined using the drop count technique as described by Bartram \& Rees (2000). Hundreds of frustules per slide were counted and identified by species according to Prescott (1977) and APHA (1998) under $1000 \times$ oil immersion microscopic lens. Conventional norms of frustule size, shape, and ornamentation were used to identify diatoms. The togetherness or separateness of the frustules determined the counts. Identification was done using the valve view, although the girdle view were also identified and counted.

\section{Analysis of physicochemical parameters}

Water temperature readings were taken in situ using a ( $\left.{ }^{\circ} \mathrm{C}\right)$ mercury thermometer. This was done by immersing the thermometer into the pond water and taking the readings. The $p \mathrm{H}$, total dissolved solids (TDS) and electrical conductivity (EC) were measured using a Hannan Instrument (Portable $\mathrm{PH} / \mathrm{EC} / \mathrm{TDS} /$ Temperature Meter) Model No. H1991300. Dissolved oxygen (DO) and biochemical oxygen demand (BOD) were determined using the azide modification of the Winkler method (Lind, 1979). Water samples in $250 \mathrm{ml}$ BOD stoppered bottles were fixed in the field with $2 \mathrm{ml}$ manganous sulphate, followed by $2 \mathrm{ml}$ alkaline-iodideazide and $2 \mathrm{ml} \mathrm{H}_{2} \mathrm{SO}_{4} .101 \mathrm{ml}$ of the sample water was titrated against $0.012 \mathrm{~N}$ sodium thiosulphate until it turned to pale yellow. 1 $\mathrm{ml}$ of starch solution was added which turned the colour of the solution to blue. The titration continued until the blue colour disappeared. The volume of the $0.0125 \mathrm{~N}$ sodium thiosulphate titrant used is equivalent to the mg of dissolved oxygen per litre (Lind, 1979). 
Total hardness and phenolphthalein alkalinity were determined using the procedure of Lind (1979). This was determined by diluting $25 \mathrm{ml}$ water sample to $50 \mathrm{ml}$ with distilled water. $2 \mathrm{ml}$ of buffer and $0.1 \mathrm{~g}$ Eriochrome black - T-dye were added. The resultant reddish solution was titrated with EDTA-titrant drop by drop until a blue colour end point was observed. The calculation was based on the equation given by Lind (1979) and APHA (1998). Nitratenitrogen and phosphate-phosphorus were determined using a $\mathrm{HACH} \mathrm{DR} / 2000$ direct reading spectrophotometer. Nitrate-nitrogen was determined using the phenoldisulphonic acid method as described by Mackereth (1963). $100 \mathrm{ml}$ of water sample was evaporated to dryness followed by the addition of $2 \mathrm{ml}$ phenoldisulphonic acid to the residue and left for $10 \mathrm{~min} .15 \mathrm{ml}$ of distilled water was added followed by $5 \mathrm{ml}$ strong ammonia solution. The resultant yellow mixture was stirred and allowed to cool.

The absorbance was measured at $410 \mathrm{~nm}$ with the spectrophotometer using distilled water as the blank. The $\mathrm{NO}_{3}-\mathrm{N}$ concen-tration was read from a calibration curve. Phosphate phosphorus was determined using Deniges method (Mackereth, 1963; Lind, 1979; APHA, 1985). One millilitre of Deniges reagent and 5 drops of stannous chloride were added to $100 \mathrm{ml}$ water sample. Absorbance at $\begin{array}{llllll}6 & 9 & 0 & \mathrm{n} \mathrm{m} & \text { w a } \mathrm{s} & \mathrm{m} \text { e a s u r e d }\end{array}$ spectrophotometrically using water as the blank. The $\mathrm{PO}_{4}-\mathrm{P}$ concentration of water sample was read from a calibration curve.

\section{Data analysis}

Means and their standard errors were computed using the microsoft office excel 2007. Shannon diversity index, Dominance and Evenness were computed using PAST for windows statistical software.

Shannon diversity index, $H^{\prime}$ (Shannon, 1948) $=$

$H^{\prime}=-\sum_{i=1}^{S}\left(p_{i} \ln p_{i}\right)-[(S-1) / 2 N]$

where $n$ is the number of individuals in species i; the abundance of species i. $S$ is the number of species. $N$ represents the total number of all individuals. $p$ is the relative abundance of each species, calculated as the proportion of individuals of a given species to the total number of individuals in the community:

Simpson's dominance index, c (Simpson, 1949):

$$
c=\sum_{i=1}^{S}\left(\frac{n_{i}}{N}\right)^{2}
$$

where $n_{\mathrm{i}}=$ number of individuals in the 'ith' species; $\mathrm{N}=$ total number of individuals; $\mathrm{S}=$ total number of species.

Species evenness $\left(J^{\prime}\right)$ represented by the Pielou's evenness index (Pielou, 1966) =

$$
.^{\prime} \frac{H^{\prime}}{H_{\max }^{\prime}}
$$

where $\mathrm{H}^{\prime}$ is the number derived from the Shannon diversity index and H' max is the maximum value of $\mathrm{H}^{\prime}$, equal to:

$$
H_{\text {uias }}--\sum_{i=1}^{S} \frac{1}{5} \ln \frac{1}{S}-\ln S
$$

Diatom data obtained were subjected to cluster analysis using Euclidean distance measurements to determine similarity in their occurrence and abundance in the different ponds. Canonical correspondence analysis (CCA) (Ter, 1986) using the 
XLSTAT-ADA software was used to detect cause and effect relationships between environmental parameters and diatom species diversity and density. Only well represented species, with more than $25 \%$ occurrence in all the study ponds, were used for the CCA analysis. Significance of the ordination axes was determined by the Monte Carlo permutation test using 500 permutations (Legendre \& Legendre, 1998).

\section{Results}

Physicochemical parameters of ponds

Total dissolved solids (TDS) had values that ranged between 97-179 $\mathrm{mg} \mathrm{l}^{-1}$ in all ponds throughout the period of the study. More dissolved substances were observed in the rainy months than the dry months in Danmika and Aviation quarry (124.67 mg 1. and 118.33 mg 1-, respectively), while Mairabo and Kabama ponds had highest values (120.33 $\mathrm{mg} \mathrm{l}$ and $80.33 \mathrm{mg} \mathrm{l}^{1}$, respectively) in the dry months. Danmika pond was most acidic (4.98) in the dry season, while Aviation quarry, with the highest $p \mathrm{H}$ values, was more or less neutral in the dry and rainy months (7.89 and 7.46, respectively) (Table 2).

Water temperature readings showed that in the dry and rainy months the ponds had average temperatures of $27{ }^{\circ} \mathrm{C}$, though Danmika pond had a low average temperature reading of $17.63{ }^{\circ} \mathrm{C}$ in the dry months. Dissolved oxygen (DO) was generally low as only Kabama pond had DO concentrations greater than $4.00 \mathrm{mg} \mathrm{1.}$. DO values were generally higher in the rainy months in all ponds than the dry months. In terms of alkalinity and water hardness, Aviation quarry pond had the highest value throughout the period of the study. Phosphate phosphorus ( $\left.\mathrm{PO}_{4}-\mathrm{P}\right)$ concentrations were higher in the rainy months in all ponds except
Aviation quarry pond. Nitrate-nitrogen $\left(\mathrm{NO}_{-}-\right.$ N) concentrations in all ponds, on the other hand, followed an opposite trend to what was obtained in $\mathrm{PO}_{4}-\mathrm{P}$ concentrations, as higher concentrations were recorded in the dry season (Table 2).

\section{Bacillariophyta}

Fifteen diatoms families spread into 23 genera and species were recorded from the four seasonal ponds studied (Table 3). Twenty two of the species were observed in the dry months of November, December and January; eight species in the rainy months of May, June and July. Total species composition showed a general trend in all four ponds, with the highest number of species recorded in the months with no rainfall. On the other hand, the months with rainfall consistently had lower number of species recorded (Fig. 1). Danmika pond had the highest number of 13 species recorded in the dry season, while Aviation quarry pond, with the lowest number of seven, was recorded. Achnanthes coarctata had the highest relative abundance in the different ponds as it was present in all the ponds in all the study months. It was closely followed by Navicula digitoradiata with a relative abundance of $87,5 \%$ in all the ponds (Table 3). Amphiprora paludosa, Biddulphia laevis, Hydrosera triquetra, Melosira granulate, Brebsissonia boeckii and Denticula elegans were all recorded $(R A=12.5)$ only in the dry months and only in Danmika pond. Anomoeneis sphaero-phora was only observed in the wet months.

The results of diversity indices of the recorded diatom taxa per pond and over the whole study period are as shown in Fig. 2a-c. In December 2005, Kabama pond had the 
highest Shannon diversity index (1.61) and was closely followed by Danmika pond (1.53). In addition, these values, which were the highest Shannon diversity indices observed throughout this study, were observed in the month of December (Fig. 2a.). The rainy month of June had the least diversity index of 0.64 which was recorded in Kabama pond. In terms of dominance, the highest value was 1.00 , and this was only observed in December (Mairabo pond), June (Danmika pond), July (Aviation quarry pond) and August (Mairabo pond). The lowest dominance value was 0.20 and was observed in Kabama pond in December (Fig. $2 \mathrm{~b}$.). As in the case of dominance, evenness values followed the same trend. The highest evenness value was 1.00 and was recorded in December (Mairabo pond), June (Danmika pond), July (Kabama pond and Aviation quary pond), and August (Danmika pond and Mairabo pond). On the other hand, the least evenness value (0.66) was recorded in Danmika pond in December 2005 (Fig 2c.).

Cluster analysis of diatom data showed close similarity in terms of species composition and occurrence per pond. This differentiation was clear between the ponds with respect to diversity and density per $\mathrm{ml}$ of diatoms in the rainy months and those in the dry months (Fig. 3). In the rainy months, Mairabo pond and Aviation ponds were clustered together with an Euclidean similarity value of -3.75 E03, while Kabama pond slightly branched away from these two ponds with a value of -5.0 E03 (Fig. 3). Danmika pond was branched further away from the rest of the ponds in the rainy months and had a value of -1.0 E04. In the dry months, the cluster had two main branches, 


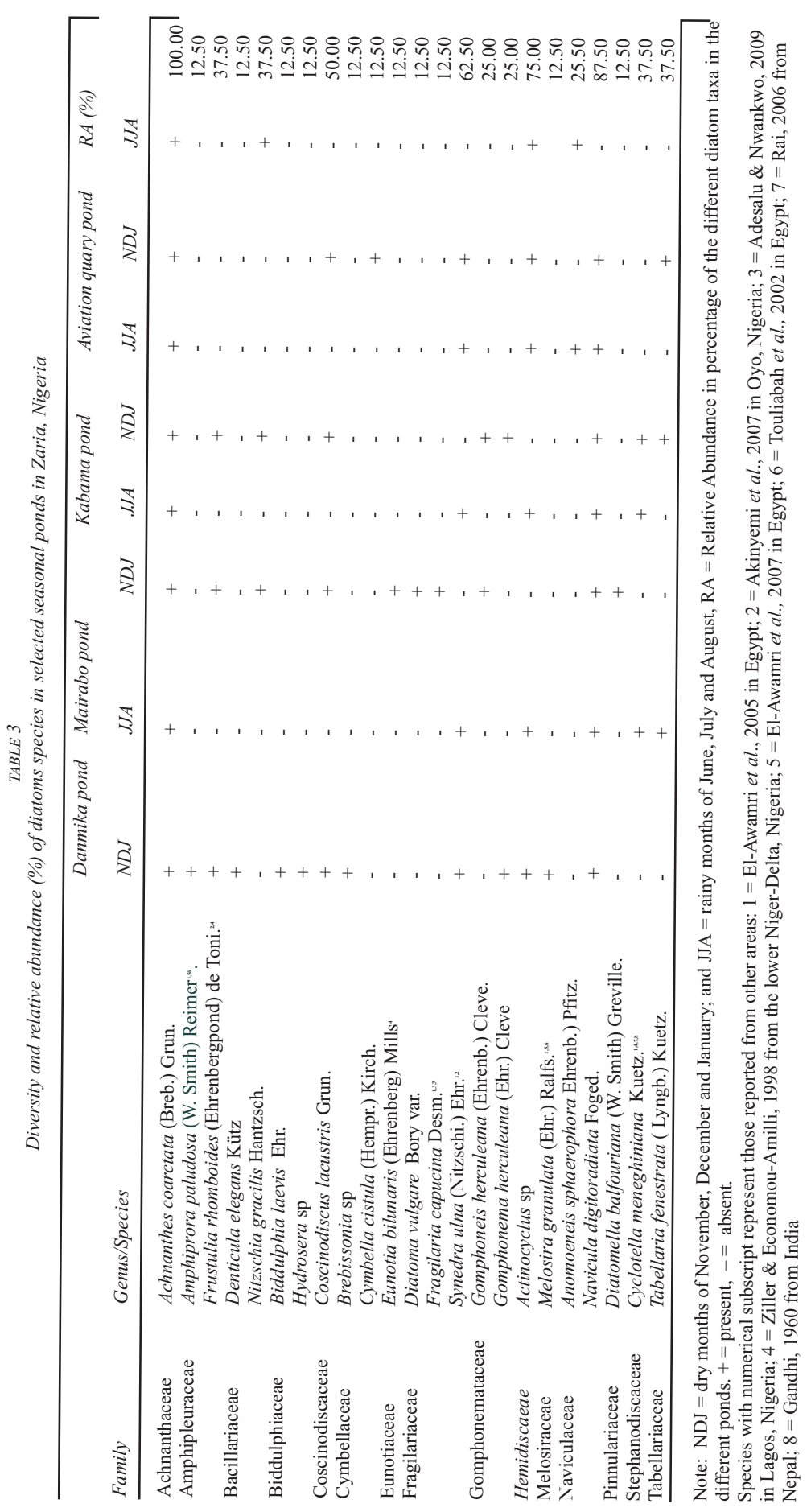




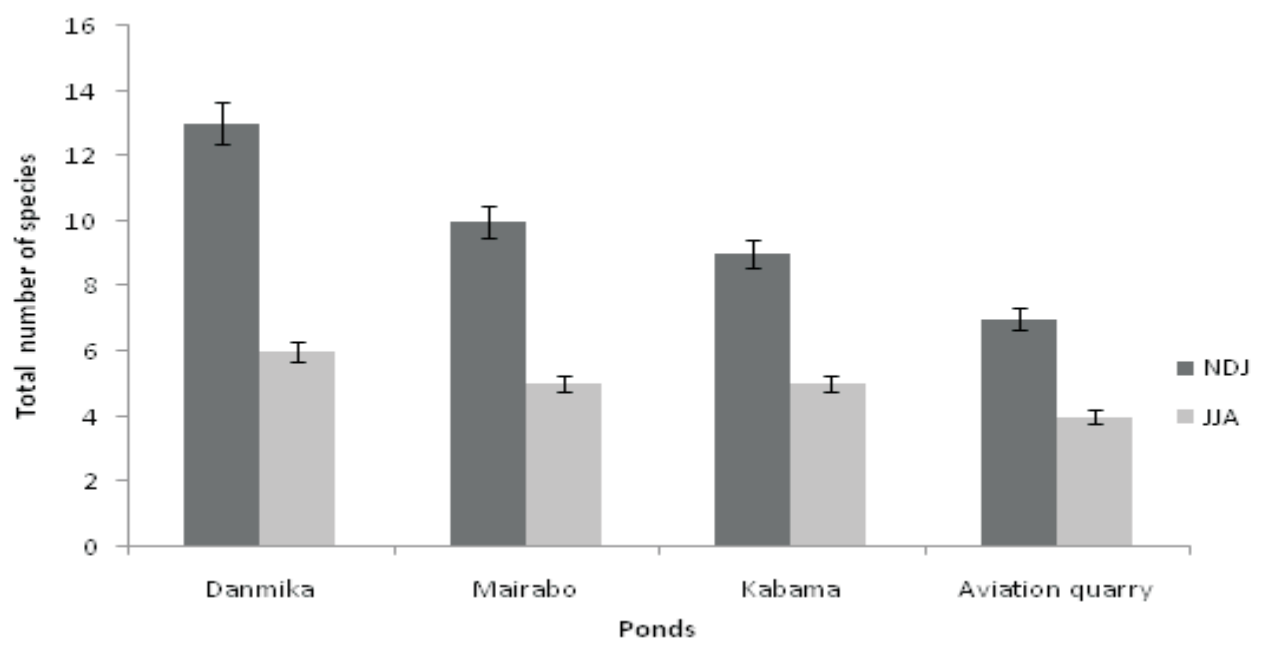

Fig. 1 : Total number of diatom species recorded in the dry months (NDJ = November, December and January) and rainy months (JJA = June, July and August) in selected seasonal ponds in Zaria, Nigeria.

one containing Mairabo pond and Aviation quarry pond (-2.0 E04), while the other subcluster had Kabama pond (-4.25 E04). Danmika pond formed a distinct cluster from the rest of the ponds with a similarity value of $-3.0 \mathrm{E} 05$, which is very distant from the rest of the ponds.

The occurrence and density per $\mathrm{ml}$ of diatoms in the different ponds showed close significant relationship $(P<0.05)$, with several of the physicochemical parameters analyzed in the present study. Navicula digitoradiata was significantly and positively correlated $(P<0.05)$ with $p \mathrm{H}$ in Mairabo pond. Coscinodiscus locustris was significantly and positively correlated $(\mathrm{P}<$ 0.05 ) with DO (Danmika pond), $\mathrm{NO}_{3}-\mathrm{N}$ (Mairabo pond), temperature (Aviation quarry pond) and alkalinity (Aviation quarry pond). Furthermore, Coscinodiscus locustris was significantly and negatively correlated $(P<0.05)$ with $\mathrm{DO}$ and $\mathrm{PO}_{4}-\mathrm{P}$ in Kabama pond. A notable observation with $C$. locustris was that in all the ponds studied it showed significant correlation with one or more physicochemical parameters.

Cyclotella meneghiniana had significant positive correlation with one or more physicochemical parameters in three out of the four ponds studied. These parameters were alkalinity (Danmika and Mairabo ponds), water hardness (Mairabo pond); $\mathrm{PO}_{4}$ $\mathrm{P}$ (Mairabo pond), TDS, temperature and $\mathrm{NO}_{-}-\mathrm{N}$ (Kabama pond). CCA results showed that Synedra and Actinocyclus were closely associated with TDS, DO and water hardness. Nitzschia, Frustulia, Navicula and Coscinodiscus were closely associated with $\mathrm{NO}_{3}-\mathrm{N}$ and alkalinity. Furthermore, Cyclotella, Tabellaria and Achnanthes were related to phosphate phosphorus levels (Fig. 4). The eigenvalues of the first two canonical correspondence analysis (CCA) axis were 0.224 and 0.089, respectively (Fig. 5). Constrained inertia (\%) was found to be 55\% 

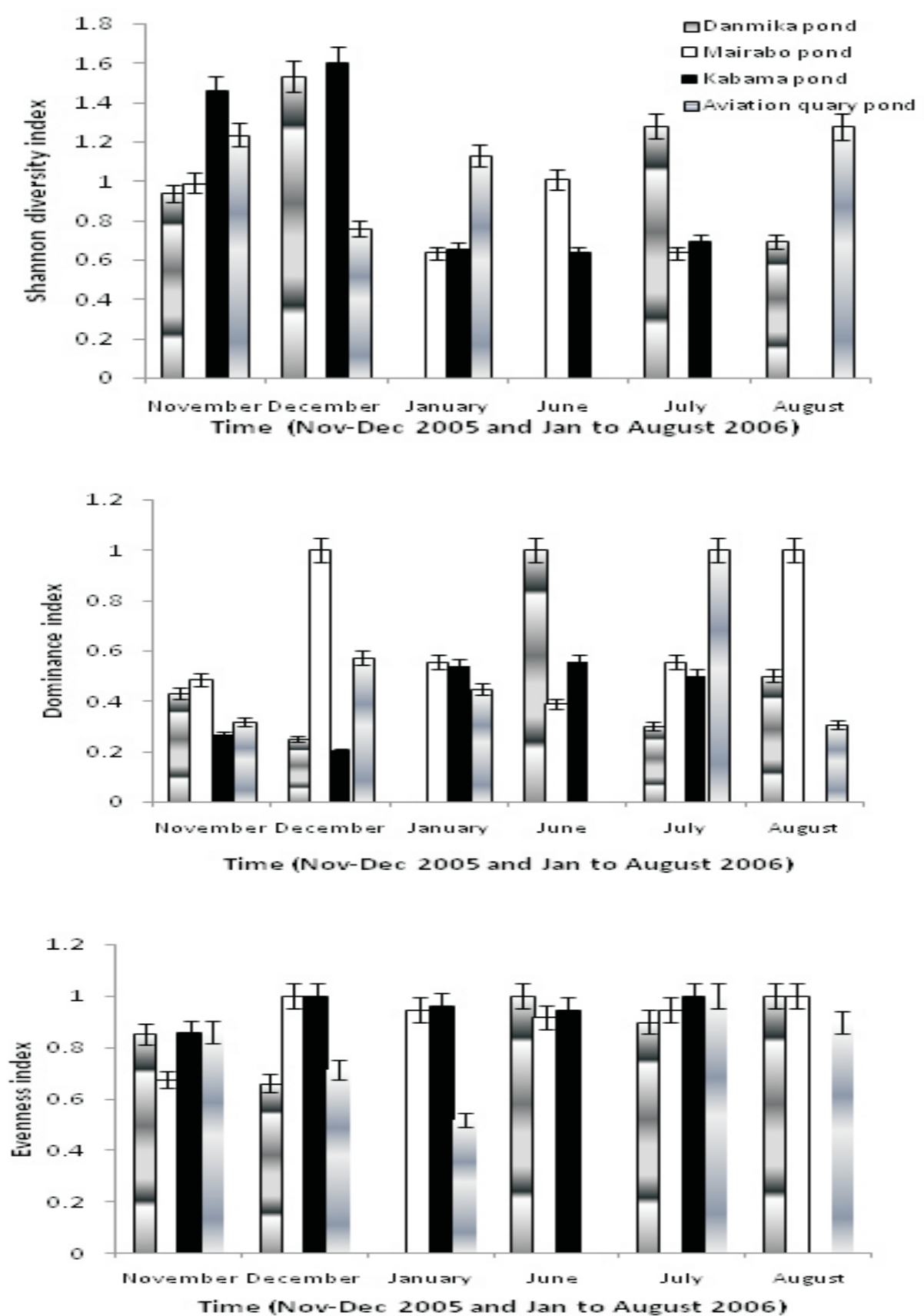

Fig. 2. Diversity indices of diatom species recorded in the different study months: (a) Shannon Diversity Index (b) Dominance and (c) Species Evenness 


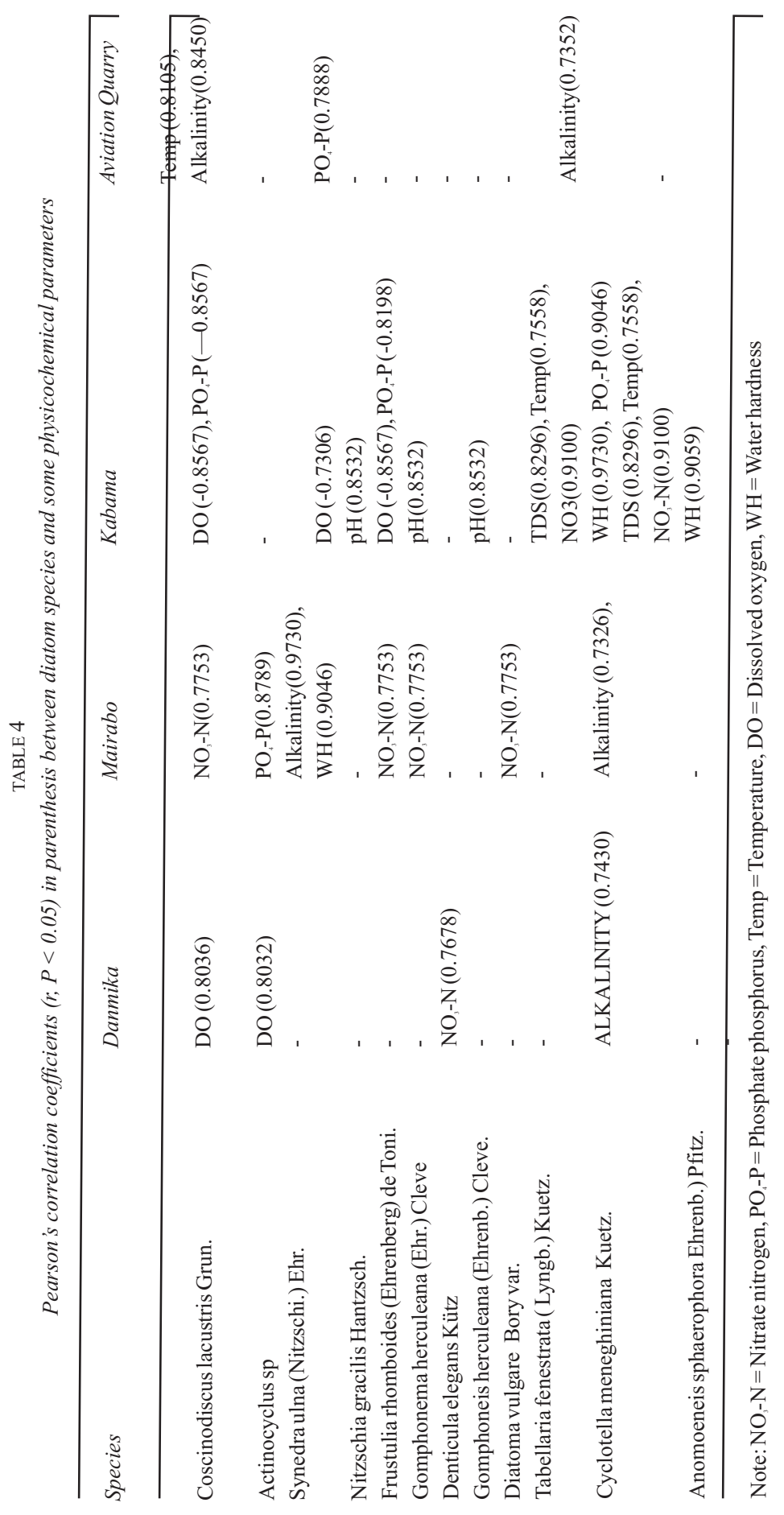




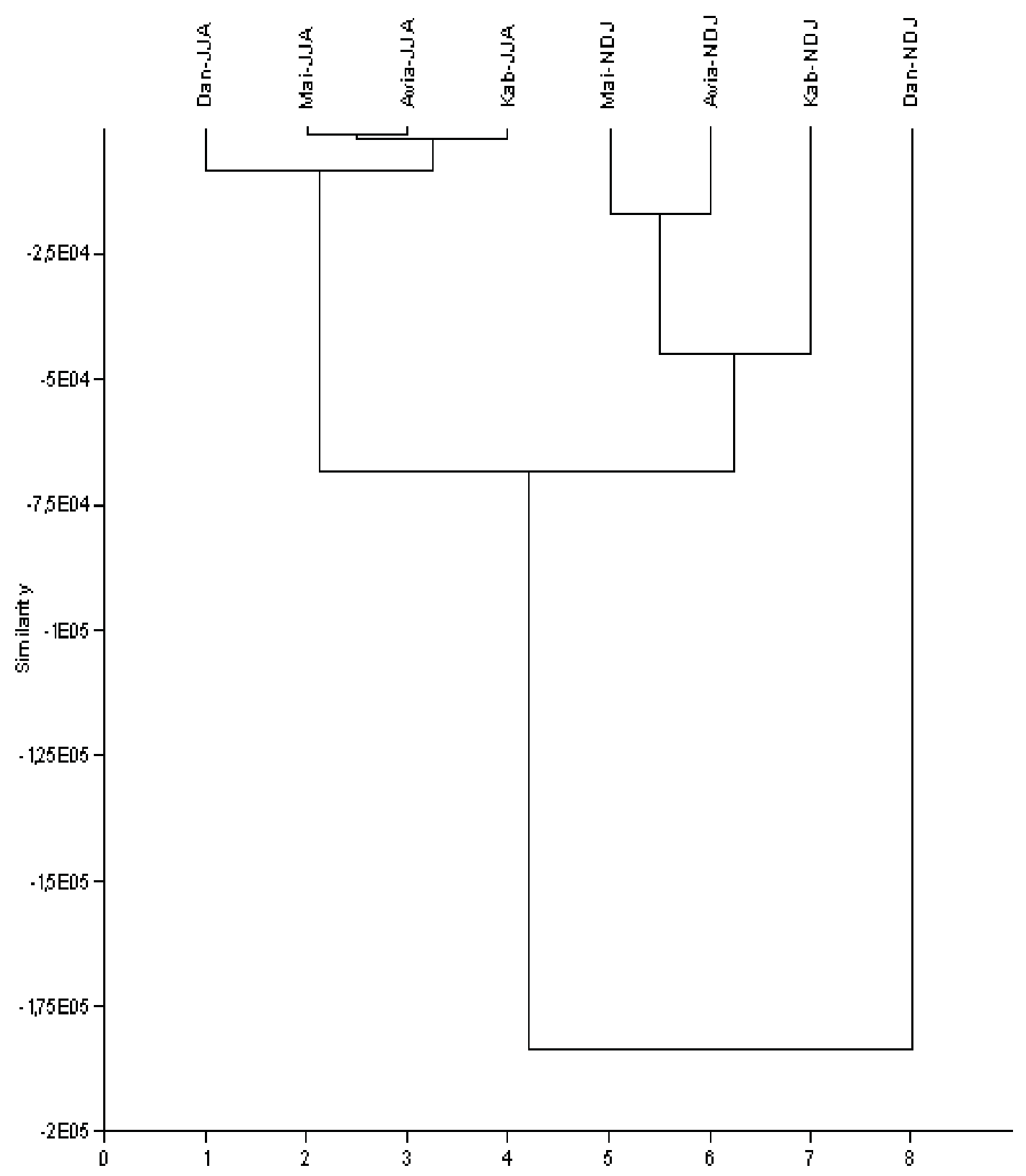

Fig. 3. Euclidean similarity measure of the occurrence of diatoms in the different ponds throughout the study period. Where NDJ= dry months of November, December and January; JJA= rainy months of June, July and August. Dan = Danmika pond, $\mathrm{Mai}=$ Mairabo pond, $\mathrm{Kab}=$ Kabama pond and Avia = Aviation quarry pond 


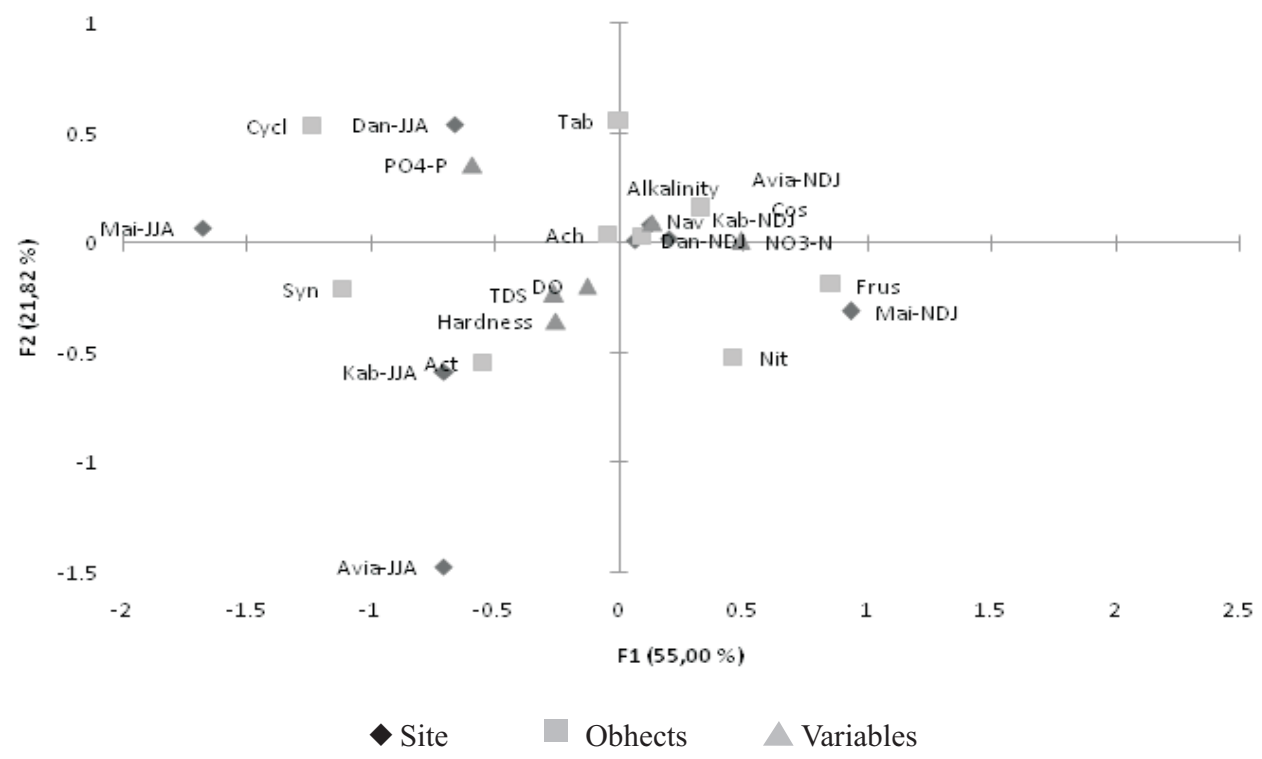

Fig. 4. Canonical corresponding analysis of planktonic diatom taxa in the different seasonal ponds. Where $\mathrm{Cycl}=$ Cyclotella, $\mathrm{Tab}=$ Tabellaria, Ach $=$ Achnanthes, $\mathrm{Nav}=$ Navicula, $\mathrm{Cos}=$ Coscinodiscus, Frus $=$ Frustulia, Nit $=$ Nitzschia, Act $=$ Actinocyclus, and Syn = Synedra . While NDJ = dry months of November, December and January; JJA = rainy months of June, July and August. Dan = Danmika pond, Mai = Mairabo pond, Kab = Kabama pond, Avia = Aviation quarry pond

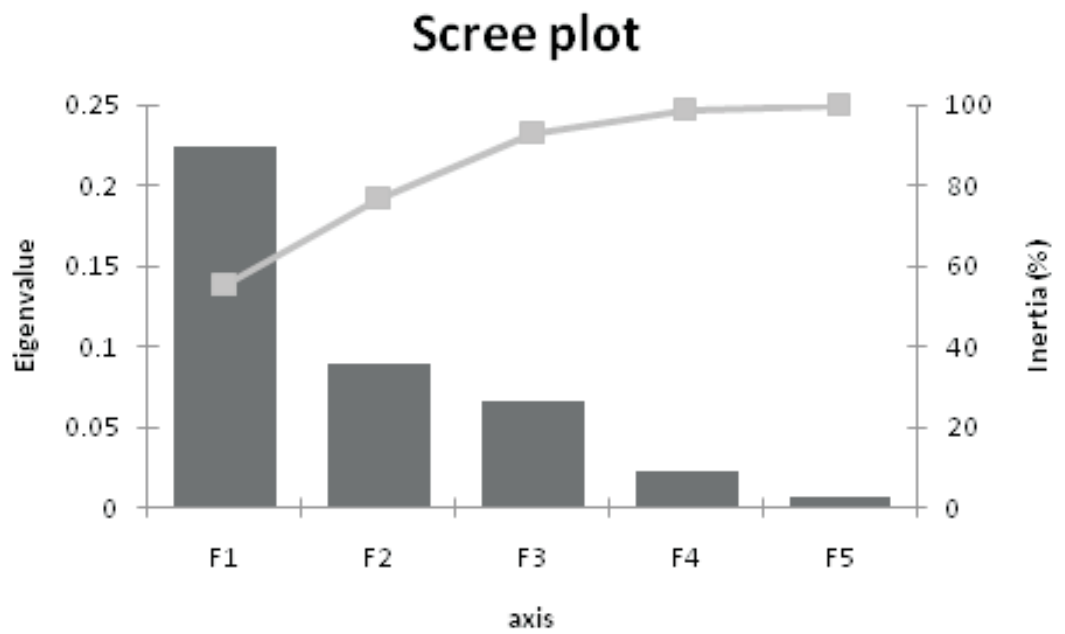

Fig. 5. Scree plot of the constrained inertia (\%) and eigenvalues in the first five (F) axis of the current study 
in the first (F1) axis and 22\% in the second (F2) axis (Fig. 5).

\section{Discussion}

The lack of temperature variation in the ponds is a common characteristic associated with tropical climates (Gobo, 1988; Chindah \& Pudo, 1991). The relatively low temperature of the water in the ponds in the dry season in Danmika pond is probably due to a reduction in water volume and the direct effect of the Harmattan, which is characteristic of northern Nigeria. Total dissolved solids (TDS) of these ponds varied probably as a result of substances entering them from neighbouring settlements and farmlands (Chapman \& Krammer, 1991; Akin-Oriola, 2003). Values of dissolved solids obtained from these ponds lie within the range obtainable in Nigeria and other African countries (Hare \& Carter, 1984; Adeniji \& Mbagwu, 1990; Odhiambo \& Gichuki, 2000; Magadza, 2003; Ndebele \& Magadza, 2005). The recorded high values of TDS, $\mathrm{NO}_{3}-\mathrm{N}$, water hardness and alkalinity in the dry months may be due to reduced water level through evaporation and irrigation, which result in higher levels of these parameters.

DO was higher in the wet season, possibly because of wind action that enhances mixing of atmospheric oxygen with water. Dissolved oxygen is essential to most aquatic organisms and is greatly affected by their metabolism (Touliabah et al., 2002). Anthropogenic activities around the catchments like farming and sewage from homes may be implicated for increases in phosphate phosphorus in the rainy months (Chapman \& Krammer, 1991; Akin-Oriola, 2003). The catchments of three out of the four ponds are farmed all year round, and surface runoff from these farms could result in elevated levels of phosphates in these ponds. In addition, most of the farmers in these catchments use inorganic fertilizers that are known to be rich in phosphates and nitrates.

The changes in diatom populations in these ponds could be attributed to their nourishment at different environmental conditions (Raupp et al., 2009). These changes are supported by the close correlation with changes in physicochemical parameters. The observed significant relationships between diatoms and some physicochemical parameters are not surprising. This is because other authors have also recorded significant relationships with some of these diatom species. For example, Cyclotella meneghiniana is known to significantly correlate with alkalinity, phosphates and water hardness (Lacerda et al., 2004). This agrees with the findings in the present study. Frustulia rhomboides has also been implicated to show close association with nitrates, dissolved oxygen, phosphates and $p \mathrm{H}$. In addition, Coscinodiscus lacustris is also reported to have its occurrence in aquatic environments tied to the physicochemistry of the system. Amongst these physico-chemical parameters are dissolved oxygen, nitrates, alkalinity and temperature (Negro et al., 2003; Vercellino \& Bicudo, 2006).

The availability or levels of water in the ponds to a great extent ensured a higher diatom species count. This was demonstrated where diatom diversity consistently showed high values in the dry months characterized by low water level. When water level is reduced by evaporation or excessive use from irrigation, the amount of nutrients become more concentrated. This could lead to concentration of nitrates and 
phosphates, thereby, promoting corresponding surge in the diversity and density of diatoms. The higher diversity of diatoms in the dry months is further supported by the estimated Shannon diversity indices and dendrograms from cluster analysis. A lower diversity and abundance in the rainy months could be attributed to a higher dilution level, which results in reduced amount of nutrients available for diatoms in the pond. In addition, Danmika pond was clearly separated from the other ponds in the multivariate analysis (Euclidean similarity) in terms of species diversity and abundance.

\section{References}

Acs E., Szabo K., Toth B. and Kiss K. T. (2004). Investigation of Benthic algal communities especially diatoms of some Hungarian streams in connection with reference conditions of the water framework directives. Acta bot. hung. 46 (3-4): 255-277.

Adeniji H. A. and Mbagwu I. G. (1990). Study of some physico-chemical factors and heavy metals in the Jakara reservoir, Kano State, Nigeria. Natural Institute of Freshwater Fisheries Resources (NIFFR); Annual Report.pp. 136-140.

Adesalu T. A. and Nwankwo D. I. (2009). A Checklist of Lekki Lagoon Diatoms. Int. J. Bot. 5 (2): $126-134$.

Akin-Oriola G. A. (2003). On the phytoplankton of Awba reservoir, Ibadan, Nigeria. Revista de Biologia Tropicall Revta. Biol. trop. 51: 1-15.

Akinyemi S. A., Nwankwo S. A. and Fasuyi A. O. (2007). Diatoms as Indicator of Pollution in Awon Reservior, Oyo Town, Nigeria. Res. J. Microbiol. 2(3): 228-238.

American Public Health Association (APHA). (1985). Standard methods for the examination of water and waste water. American Water Works Association/Water Environmental Federation, Washington DC.

American Public Health Association (APHA). (1998). Standard methods for the examination of water and wastewater, 20th edn. American Water
Works Association/Water Environmental Federation, Washington DC.

Bartram, J. and Rees G. (2000). Monitoring Bathing Waters - A practical guide to the design and implementation of assessments and monitoring programmes. World Health Organisation.

Bogaczewicz-Adamczak B., Klosinska D. and Zgrundo A. (2001). The diatoms as indicators of water pollution in the coastal zone of the Gulf of Gdansk (Southern Baltic Sea). Oceanologia. St. 30 (3-4): 59-75.

Chapman L. J. and Kramer D. L. (1991) Limnological observations of an intermittent tropical dry forest stream. Hydrobiologia. 226: 153-166.

Chindah A. C. and Pudo J. (1991). A preliminary checklist of algae found in plankton of Bonny River in Niger Delta, Nigeria. Fragm. flor. geobot, 36 (1): 112-126.

Ezra A. G. (2003). Studies on diatoms of Bruckish water pond in Lagos, Nigeria. Proceeding of the 8 th National Conference on the Application of Science for National Development and Exhibition. Held at the Federal Polytechnic, Mubi 25th-28th June 2003, pp. 51-53.

Gobo A. E. (1988). Relationship between rainfall trends and flooding in the Niger Delta-Benue River Basin. J. Met. UK 13 (132): 220-224.

Hare L. and Carter J. C. H. (1984). Diel and seasonal physico-chemical fluctuations in a small natural West African lake. Freshwat. Biol. 14: 597-610

Kadiri M. and Opute F. (2003). SEM observations of some noteworthy diatoms from the Ikpoba reservoir, Nigeria. Pl. Biosyst. 137(2): 215-229.

Lacerda S. R., Koening M. L., Neumann-Leitao S. and Flores-Montes M. J. (2004). Phytoplankton nyctemeral variation at a tropical river estuary (Itamaracá - Pernambuco - Brazil). Braz. J. Biol. 64 (1): 81-94.

Legendre P. and Legendre L. (1998). Numerical ecology, 2nd edn. Elsevier Science BV, Amsterdam.

Lind O. T. (1979). A handbook of limnological methods. CV Mosby Co., St. Louis. 199 pp.

Mackereth F. J. H. (1963). Some methods of water analysis for Liminology scientist. Freshwater Biology Association publication.

Magadza C. H. D. (2003). Lake Chivero: A management case study. Lakes Reserv. Res. Mgmt. 
8: 69-81.

Nakanishi Y., Michiaki S., Yumita K., Yamada, T. and Honjo T. (2004). Heavy-Metal pollution and its state in algae in Kakehashi river and Godani river at the foot of Ogoya Mine, Ishikawa Prefecture. Analyt. Sci. 20: 73-78.

Ndebele R. and Magadza C. H. D. (2005). The phytoplankton community of an inland lake, Zimbabwe. Proceedings of the 11th World Lakes Conference Nairobi, Kenya. 2: 248-254.

Negro A. I., De Hoyos C. and Aldasoro J. J. (2003). Diatom and desmid relationships with the environment in mountain lakes and mires of NW Spain. Hydrobiologia. 505 (1-3): 1-13.

Nwankwo D. I. and Jaiyeola M. A. (2001). Surf diatoms of the Lagos Lagoon Beach, Nigeria. $J$. aquat. Sci. 16: 35-38.

Odhiambo W. and Gichuki J (2000). Seasonal dynamics of the phytoplankton community in relation to environment in Lake Baringo, Kenya (impact on the Lake's resource mangament).; Afr. $J$. trop. Hydrobiol. Fish. 9(1 \& 2): 1-16.

Oladipo A. E. and Williams A. B. (2003). Physicochemical parameters and phytoplankton community of some selected fishponds in Lagos State, Nigeria. J. aquat. Sci. 18: 53-58.

Onyema I. C. and Nwankwo D. I. (2009). Chlorophyll a dynamics and environmental factors in a tropical estuarine lagoon. Acad. Arena. 1(1): 18-30.

Pielou E. C. (1966). The measurement of diversity in different types of biological collections. $J$. theor. Biol. 13: 131-144.

Poulkov A., Duchoslav M., and Dokulil M. (2004). Littoral diatom assemblages as bioindicators of lake trophic status: A case study from perialpine lakes in Austria. Eur. J. Phycol. 39 (2): 143-152.

Prescott G. W. (1977). The Fresh Water Algae. WMC Brown Company Publishers, Dubuque, Iowa.

Raupp S. V., Torgan L. and Melo S. (2009). Planktonic diatom composition and abundance in the Amazonian floodplain Cutiuaú Lake are driven by the flood pulse. Acta limnol. Bras. 21 (2): 227-234.

Shubert E. (1984). Algae as ecological indicators. (L. E. Shubert, ed.) Academic Press, New York.

Shannon C. E. (1948). A mathematical theory of communication. Bell Syst. tech. J. 27: 379-423;
623-656.

Simpson E. H. (1949). Measurement of diversity. Nature, 163(4148): 683-688.

Stachura-Suchoples K. (2001). Bioindicative values of dominant diatom species from the Gulf of Gdank. Southern Baltic Sea, Poland. (R. Jahn, J. P. Kociolek, A. Witkowski, P. Compere, eds), pp. 477 490. Lange-Bertalot-Festschrift: Gantner, Ruggell, Koeltz Scientific Books.

Stenger-Kovács C., Buczkó K., Hajnal E. and Padisák J. (2007). Epiphytic, littoral diatoms as bioindicators of shallow lake trophic status: Trophic diatom index for lakes (TDIL) developed in Hungary. Hydrobiologia 589 (1): 141-154.

Tapia P. M. (2008). Diatoms as bioindicators of pollution in the Mantaro River, Central Andes, Peru. Int. J. envir. Hlth 2(1): 82-91.

Ter Braak C. J. F. (1986). Canonical correspondence analysis: a new eigenvector technique for multivariate direct gradient analysis. Ecology 67(5): 1167-1179.

Touliabah H, Safik H. M. Gab-Allah M. M. and Taylor W. D. (2002). Phytoplankton and some abiotic features of El-Bardawil Lake, Sinai, Egypt. Afr. J. aquat. Sci. 27: 97-105.

Venkateswarlu V. (1981). Algae as indicators of river water quality and pollution. WHO Workshop on Biological Indicators and Indices of Environmental Pollution CPCB, New Delhi.pp. 93-100.

Venkateswarlu V. and Manikya P. R. (2000). Plant Biodiversity and Bioindicators in Aquatic Environment. Envir. News 4 http://envfor.nic.in/news/8900/plantbio.html.

Vercellino I. S. and Bicudo D. (2006). Sucessão da comunidade de algas perifíticas em reservatório oligotrófico tropical (São Paulo, Brasil): comparação entre período seco e chuvoso. Rev Brasil. Bot. 29(3): 363-377.

Vos P.C. and de Wolf H. (1993). Diatoms as a tool for reconstructing sedimentary environments in coastal wetlands: Methological aspects. Hydrobiologia 269/270: 285-296.

Whitton B. A., Rott E. and Friendrich (1991). Use of algae for monitoring rivers. Proc. Int. Symp. Dusseldorf, Germany. pp. 1-193. 